\title{
Evidence-based social service in Sweden: a long and winding road from policy to local practice
}

Kerstin J ohansson

The self-archived postprint version of this journal article is available at Linköping University Institutional Repository (DiVA):

http:/ / urn.kb.se/ resolve?urn=urn:nbn:se:liu:diva- 145649

N.B.: When citing this work, cite the original publication.

J ohansson, K., (2017), Evidence-based social service in Sweden: a long and winding road from policy to local practice, Evidence \& Policy. https:// doi.org/ 10.1332/ 174426417X15123846324591

Original publication available at:

https:/ / doi.org/ 10.1332/ 174426417X15123846324591

Copyright: Policy Press

http:// www.policypress.co.uk/ 


\title{
Evidence-based social service in Sweden: a long and winding road from policy to local practice
}

\author{
$* * *$ \\ Kerstin Johansson, Linköping University, \\ kerstin.k.johansson@liu.se
}

\begin{abstract}
It is possible to discern a new trend replacing New Public Management (NPM) in human service organisations. This trend comprises a discussion about evidence and governance with the goal of establishing a knowledge-based practice within Swedish social service. Efforts aimed at promoting an evidence-based practice have been an explicit part of Swedish social policy for more than 15 years. As a public venture aimed at changing local municipality social work practice, the initiative described in this article has few predecessors in terms of personnel, finance, or political support. The purpose of this article is twofold: first, to describe the intervention and its implementation, and second, to analyse the intervention and its implementation and some implications of them. The article uses translation and institutional theory. The overall aim is to analyse the intervention and its implementation from the perspectives of power and governance. The empirical data include documents, interviews, and a survey of professionals. Data were collected between 2009 and 2016. This article shows that the intervention has been interpreted and reinterpreted during its implementation, and that the intervention has not yet created any radical change or knowledge development in social work practice. The article argues that evidence-based governance and other forms of governance constitute a successor of NPM, though far from a complete replacement. It is also obvious that actors such as researchers, professionals, and clients seem to have limited influence over future knowledge development within social services.
\end{abstract}

Key words: governance $\bullet$ Swedish social service $\bullet$ evidence-based practice $\bullet$ translation theory

\section{Key messages}

- This intervention is a top-down project, and its implementation has not put the social workers in focus.

- The policy-intervention has not yet created any radical knowledge development in social services.

- Evidence-based governance is a successor of NPM.

- This is an example of both governance and governmentality.

\section{Introduction}

The activities and knowledge base in human service organisations (Hasenfeld, 2010; Johansson (et al 2015b) are being called into question today. Current debate primarily 
concerns organisational changes, particularly relating to the ideals promoted within New Public Management (NPM). However, it is possible to discern a new trend replacing NPM, namely different interpretations of governance (Johansson et al., 2015; Johansson, 2013). This trend comprises the debate over knowledge and best practice, often discussed as evidence-based practice (EBP) (Sacket, 2000). There is an ongoing debate about evidence and governance aimed at establishing a knowledge-based practice within Swedish human service organisations. One other important trend is the increasing amount of governance by the state and the increasing involvement of central bureaucrats as actors in this trend of governance. The new forms of governance discussed in this text are a departure from NPM in that they are complex and sometimes ambiguous regarding power and responsibility (Bouckaert \& Pollitt 2011; Johansson et al, 2015a). Governance in a broad sense can be understood as 'the framing, orientation and implementation of policies’ (Daly 2003:5).

The debate about knowledge development in Swedish social services ${ }^{i}$ has existed for a long time (Soydan 2010), but was reinvigorated from the late 1990s onwards by an opinion piece published in 1999 (Pettersson and Wigzell, 1999) and a host of articles that followed (Soydan 2010; Bergmark, Bergmark and Lundström 2012, et al). The most concrete event in this line was the Government Official Report SOU 2008:18, entitled Evidence-based practice within social services - to the benefit of the user, which formed the basis for the intervention examined in this article.

Since 2009, I have studied this intervention that is aiming to developing the knowledge base in local social service practices. ${ }^{\text {ii }}$ The intervention was implemented during 2009-2016, in three steps: 1) laying out the plan of this policy-intervention at a national level (Denvall and Johansson 2012), 2) implementation at the regional level (Johansson 2013), and 3) implementation at the local municipal social service level (Johansson and Fogelgren 2016).

The purpose of this article is twofold: first, to describe the intervention and its implementation, and second, to analyse the intervention and its implementation and some implications of them. It could be asked whether these efforts should be regarded as an intervention or merely as a set of actions taken toward EBP. I argue that these efforts should be regarded as an intervention, since the state is the initiator of the profound purpose of changing and developing the behaviour of the social services through a democratic process.

To describe and discuss the intervention and its implementation at the regional and local level, I use institutional theory and concepts such as idea dissemination and 
'travel'. The intention and overall aim is to analyse this intervention and its implementation from the perspectives of power and governance. One important aspect of this intervention and its implementation is EBP, which is concerned with laying down general evidence-based principles to reinforce proven guidance and methods in social work and social welfare in general (e.g., Soydan 2010; Sacket 2000). Although this is an important part of the intervention and its implementation, it is not the focus of this article, nor are the so-called support structures for knowledge development that have been identified as the key to achieving EBP (Platform Agreement 2010). Instead, the focus is on the intervention and its implementation.

\section{Method and theoretical frame}

The initial data (discussed as step 1 later in the article) consisted of analyses of documents and reports such as policy proposals and evaluations by national government commissions. Step 1 also included observations, notes from workshops, conferences, seminars and meetings with actors from national, regional, and local organisations. Primarily, the data consisted of some thirty interviews with actors in this field during 2010-2015 (steps 1-2). These actors were mostly managers and experts from the national and regional government. Additional data were drawn from a survey of 317 professionals that was conducted in 2015, with a response rate of nearly $60 \%$. The survey included seven interviews and focused on the professionals' views of and understanding of EBP. A small participant observation study of a local attempt of network governance was conducted in step 3. This observation study included three observations, each about six hours long, during the start of this network. Unfortunately, the network was closed after one year when the social services manager ended his employment. All empirical data were collected between 2009 and 2016. The empirical data represent a relevant base for this case study, and are analysed using both thematic analysis and inductive content analysis (Vaismoradi et al 2013; Braun \& Clarke 2014).

\section{Translation theory}

Translation theory is used to capture how the idea of this intervention has been handled. Research on how ideas are translated; that is, how they are interpreted by actors and then subsequently spread, has only a brief history in Sweden (Røvik 2000). An article by Bruno Latour was of vital importance to Czarniawska and Bernward (1996), who used it together with Berger's and Luckmann's theory of institutionalisation processes to create what is known as a 'translation model' (Czarniawska and Bernward 1996:26). 
This model deals with how ideas are translated, rather than transferred. In oversimplified terms, Berger \& Luckmann (1966) describe a process of institutionalisation through internalisation, where the final phase involves the institutionalisation of values and habits (Berger and Luckmann, 1966). Instead of describing how people undergo institutionalisation processes, as Berger and Luckmann do, Czarniawska and Bernward $(1996,1998)$ elevate the idea to the organisational level, which is central in this article.

The analysis also uses new institutional theory when discussing human services organisations as institutional practices. One way to understand such processes is by considering them as a kind of diffusion process where ideas are spread through vigorous policies implemented, for example, through mandatory legislation and treatment guidelines issued by the National Board of Health and Welfare. Instead of being a precise concept, this intervention represents a stream of ideas that actors interpret according to their beliefs and definitions of problems (Johansson 2013; Johansson et al. 2015a). The present article therefore also takes an interest in the unpacking of this stream of ideas into a local concept and its adaptation.

\section{Idea dissemination within an organisational field}

The intervention examined here can be seen as a process within an organisational field characterised by various levels and actors with various positions and power. At the national level, we find the primary responsible authorities: the Swedish Association of Local Authorities and Regions (SALAR), the Ministry of Health and Social Affairs, and the National Board of Health and Welfare. There is also a regional level, comprised of county and regional associations (or similar organisations), and at the local level we find local social service practices with professionals and users. The actors also include research and development units (Alexandersson et al. 2009), users' organisations, and researchers at universities, all of which, to a greater or lesser degree, operate on all three levels (Johansson 2013:102).

\section{Swedish social services organisation}

When discussing this intervention, it is important to understand how Swedish social services are organised. In Sweden, social services legislation funds the provision of social services that involve central government agencies, 290 municipalities, and 20 regional governments. SALAR is the central organisation for Sweden's municipalities and regions. The municipalities are the front-line organisations charged with providing social services. Municipal social services (Socialtjänst) have been operating in their 
current form since 1980. The central government operates through the National Board of Health and Welfare (Socialstyrelsen).

In 2007 the Ministry of Health and Social Affairs (Socialdepartementet) established the Commission on Knowledge-Based Social Care Services to prepare a proposal for further measures designed to produce knowledge for dissemination and practical use. This commission also examined how state funds currently invested in the social services system might support the development of practice-pertinent knowledge. The commission presented its joint proposal, SOU 2008:18, in 2008, stating that Sweden's long-term goal should be to develop EBP in social services: 'We mean by evidence-based practice, a practice based integration of the user's experience, the expertise of the professional, and the best available scientific knowledge' (SOU 2008:18:10). The following section of this article unpacks and analyses this intervention and its implementation.

\section{Findings}

Although the purpose of this article is to describe and analyse the intervention and its implementation, there are some findings and results of the intervention that are also of interest. Here follows first a description of the intervention and then an analysis of the intervention and its implementation.

\section{The intervention}

Following the publication of SOU 2008:18, SALAR and the Ministry of Health and Social Affairs assumed responsibility for the implementation and signed an agreement with the central government in 2009 to jointly create a 'platform for evidence-based practice in social services’ (överenskommelse, engs agreement Ök 2009). As a national public venture aimed at changing frontline social welfare activity, this intervention has few predecessors in terms of personnel, finance, or political support (Johansson, Denvall and Vedung 2015; Bergmark, Bergmark and Lundström 2012; Bergmark and Lundström 2006).

The foundation for this intervention and its annual 'agreements' (Ök 2009-2016) was the assessment that the central government could better support the development of knowledge-based social services. The platform agreement states:

This platform specifies the focus of agreements between the government and the Swedish Association of Local Authorities and Regions (SALAR) concerning coordinated and long-term efforts to provide support for evidence-based practice in social services... (Ök 2010) 
It is here that we begin to discern the dissemination of ideas and the intervention's 'journey', which we will return to later. The implementation is to be achieved by creating support structures at the local level. The regional levels (step 2) are highlighted as important links between the national (step 1) and local levels, with the goal of changing the local social services (step 3). An overview of the intervention and its implementation is given in Figure 1.

Figure 1. Overview of the intervention and its steps.

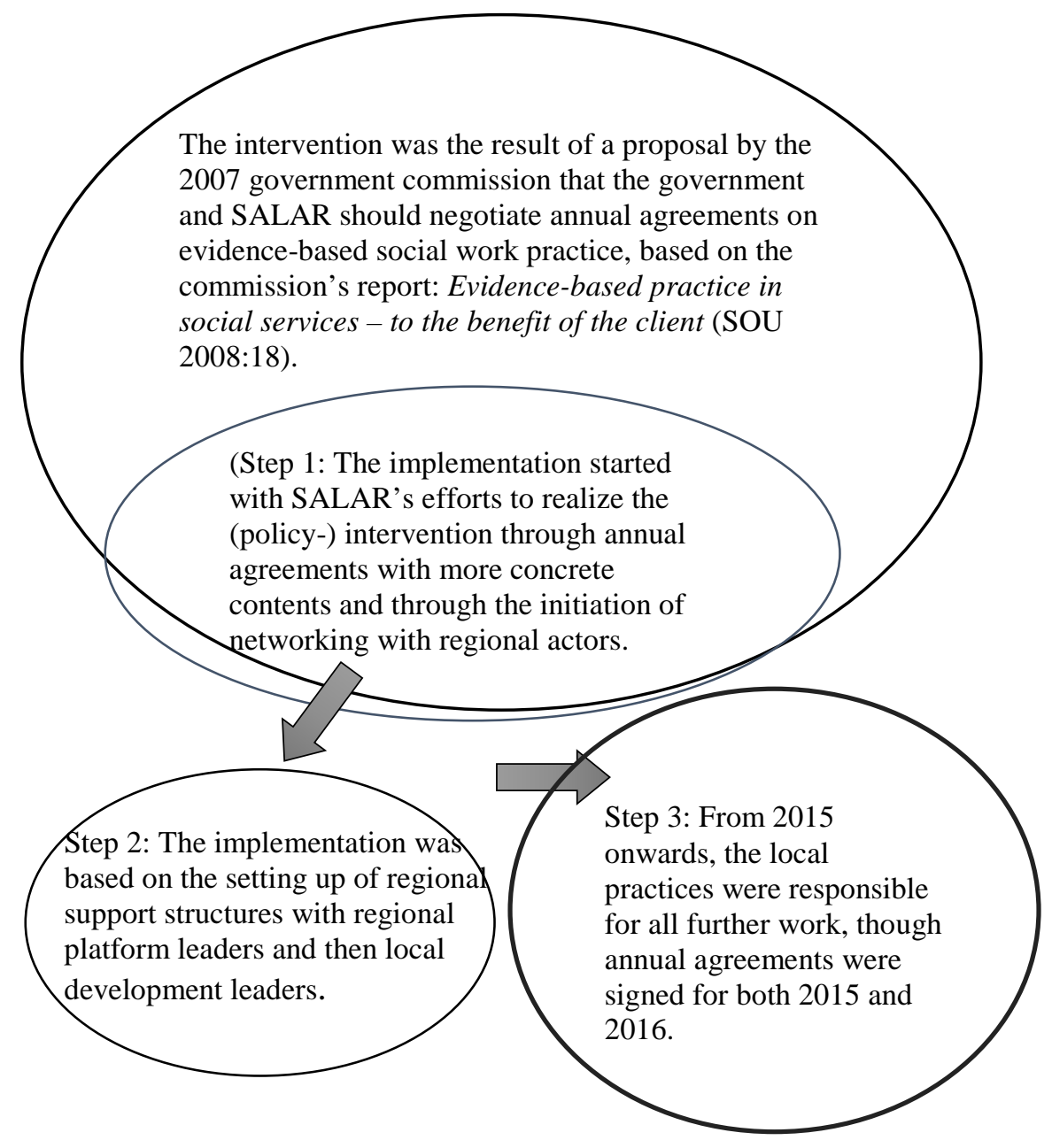

The intervention proposals presented in the form of initiatives are formulated somewhat differently (see also Ök 2010 and 2011), but include:

- Regional support for knowledge development

- Support for local development and improvement work

- Web-based documentation for local and national follow-ups

- Research 
- Education and further education

- Cooperation

- User participation

\section{The implementation}

\section{Step 1: the national level}

Step one in this implementation was mainly about who and what was to be changed. The central question in this step was how change would be achieved. The idea, more than the actual intervention itself (the what), was disseminated through conferences, workshops, and publications. An analysis of the national level (step 1) (Denvall \& Johansson 2012) revealed that the intervention's content was not well defined and was expected to be decided through negotiation; that is, the intervention's content was expected to be clarified and processed in the future.

\section{Step 2: the regional implementation}

SALAR worked intensively to begin the regional implementation in the spring of 2010. One initial concrete measure that SALAR wanted to implement was to encourage the regions to draw up joint declarations of intent in support of knowledge development and cooperation within social services and healthcare. The process progressed rapidly, and by August 2010 all counties had submitted declarations of intent (SALAR 2010).

Several of these declarations emphasised the importance of networking between the regional levels and the municipalities and their local social services. All regions were granted funds to continue working on support structures (Johansson, 2013). Certain regions already had an organisation suitable for administering and managing welfare, while others did not. Interviews showed that the declarations of intent were often composed quickly:

We have cut and pasted from existing operational documents, so, at the moment, that's what we have in our declaration of intent... (which applies generally to the whole region) but the local level is completely absent. The situation varies. (Regional representative, autumn 2010)

The declarations of intent can also be interpreted as examples of how institutionalised norms for how an organisation should look and act have been adopted in organisations with differing core activities. In comments made in 2010, regional actors described widely varying approaches to incorporating the intervention and implementing its parts: 
Approaches in the different regions have been quite mixed...SALAR probably intended that we should have a more coherent idea and organisation throughout the country. (Regional representative, autumn 2010)

In the above quotation, the regional representative calls attention to the regional organisations' importance in the intervention work (albeit perhaps unwittingly); these organisations are also institutional actors.

It's going to take an enormous amount of time before this filters through (that is, SALAR's guidelines). (Regional representative, autumn 2010)

The regional representatives felt that implementing the intervention would take time. This can be traced back to the regional organisations also being institutional actors, and organisations are often described as slow-moving. Furthermore, actors who assume responsibility for and pass an intervention on are not just transporters, but also transformers, given that they constantly adapt their work to suit their organisational and institutional affiliation. In autumn 2010, the implementation of the intervention was described as follows:

...this will be an uncertain journey. (Regional representative, autumn 2010)

The majority of regional representatives reported that they were focusing on developing existing knowledge structures, but, at the same time, they stressed the need for improved coordination and long-term planning. One year later, the representatives believed that:

A lot has happened... (Regional representative, autumn 2011)

Here they were referring to the number of workshops, meetings, and conferences that had been held over a brief period of time. The regional representatives had begun to form their own strategy for how to proceed. One example of this was a region that had chosen to strengthen its existing operation instead of hiring a 'platform manager' as directed by SALAR:

We're telling SALAR, 'We're not going to have a regional development manager. Instead... we plan to ensure that we have a contact person for each area.' (Regional representative, autumn 2011)

The regional representatives acted as institutional entrepreneurs, and their efforts to 'decouple' rhetoric from practice are clear. That is, they separated practical action from the formal structure, which allowed their organisation to keep in step with SALAR while preserving its own activity. The implementation of the intervention thus spread between autumn 2010 and autumn 2011, although not entirely in line with SALAR's 
original intentions. The Agency for Public Management (2011) wrote the following in its evaluation report:

It is too early to be able to determine whether or not the work of building regional support structures will succeed. The work has been on-going for too short a time. (Agency for Public Management, 2011 p. 46)

For the same idea to be able to travel further to the local practice (step 3), it needed to be decoupled again. Up to this point, the intervention had been implemented at the regional level and was regarded as useful, but interactions with professional social workers had not yet been a part of the implementation.

The platform initiative has been helpful for us at the regional level, but individual social workers likely don't even know what it's all about... (Regional representative, autumn 2011)

The descriptions above give a picture of the situation as of 2011. As planned, the third and last step was then initiated, and from 2015 the local practices were responsible for all further actions.

\section{Step 3: local social service practices}

The intention in the third and last step was for the ideas of the intervention to be unpacked in the local context; that is, in the municipalities' local social service practices. To get a picture of how the professionals in social work practice perceived this step of the intervention, a survey including interviews and open-ended questions was conducted in 2015. A web-based survey was sent out by email to about 200 professional social workers (Johansson and Fogelgren 2016). The results of the survey, including the interviews, show that as of spring 2015 the intervention had not changed the daily work to any great extent. There was a fundamental belief that EBP was a desirable goal, but the social workers also mentioned their limited time and the fact that there was little or no room for keeping up with the development of their work or time to think about how to do the work.

Evidence-based practice is something to strive for. But our organizations are so slimmed down and overflowing with work, that there are no time and energy left over to participate in this. Therefore, it becomes something of a paper product that managers and perhaps municipality strategists work with - not us professionals in our daily work. The EBP that trickles down to us professionals are a watered-down glimpse of something that could have been good. (Johansson and Fogelgren, 2016:24) (author's translation) 
In local practice, there was generally more focus on ensuring that the work kept up with the basic exercise of authority, dealing with cases, and decisions on action. One of the informants described the results of the intervention as a 'watered-down glimpse of something that could have become something good' (Johansson and Fogelgren $2016 \mathrm{p}$ 24).

The fact that one of the professionals perceived the intervention in this way is a problem both in theory and in practice. In theory, it is a problem connected to the important question of knowledge and how to decide what kind of knowledge should form the future social work. In practice, it is a problem if the professionals perceive that they are not crucial actors in the development of social work. The results of the survey show that the professionals did not feel they had more influence over the future knowledge development in social services after this intervention.

It is evident that the idea has spread: it has been unpacked, interpreted, and reinterpreted. The main interpretation is that this intervention is about using methods that are 'approved by the research' (Johansson and Fogelgren, 2016 p 27). The idea starts out on its journey, is then interpreted by several different actors, and finally becomes institutionalized and embedded as an integral part of a new practice, by which point the original idea can be more or less visible and recognizable (Czarniawska and Bernward 1996).

An intervention's journey

It is unlikely that the actors behind the SOU 2008:18 report could foresee how this intervention would travel. Its ideas have been decoupled from their original context, and this decoupling has meant that temporal and spatial characteristics have been stripped away. In this way, the idea has become 'open', and thus also open to interpretation. The processes of implementation examined in this article may resemble diffusion, but I argue that they should instead be regarded as a process of translation. The intervention has been translated and interpreted by other actors in all three of the implementation steps, and this contextual migration has made it possible to see the idea in a new light. The new context and idea-bearers' interpretations have caused the original intervention to change, at least in part. Actors who transfer ideas do something with them; they connect the original idea with their own ideas (Czarniawska and Bernward 1996:46). When translated, the original is transformed into something different. This means that actors who receive and transfer ideas are not only transporters, but also transformers. When an idea has arrived in a new context, it needs to be spread to more actors if it is to take root. 


\section{A analysis of a unclear intervention and an unsuccessful implementation}

Evidence-based practice in social services - for the benefit of the user (SOU 2008:18)

formed the basis for a now-completed intervention aimed at changing local social service practice. This policy-intervention, along with its implementation, offers an example of how all organizations encounter difficulties when implementing new interventions; this applies not least to human service organizations. As discussed above (step 1), this intervention had unclear goals, which meant that the street-level bureaucrats - in this case, the social workers - interpreted the intervention not as a policy but more literally as the introduction of new methods (step 3). In short, this intervention was complex and difficult to penetrate, understand, and implement in practice, and this is one reason why it has been so controversial.

The final official evaluation of the intervention argues that, although much remains to be done, the intervention has improved the conditions for EBP (Statskontoret 2014:18). However, the evaluators stated that 'There is still a long way to a more systematic development of knowledge’ and 'further efforts are needed to support the structures of knowledge development that have been built up if these structures are going to remain...' (ibid. p. 7, author's translation). The evaluators also noted that it can often be difficult to 'get temporary investments to live on after the end of the project' (ibid. p. 8). In conclusion, several efforts within this intervention and its annual agreements (Ök 2009-2014, 2015 and 2016) have been made, but the outcome, efficiency, and long-term sustainability of these efforts and support structures are unclear. There are several possible explanations for this lack of a new sustainable EBP. One of them has to do with the fact that this intervention was unclear from the start, and therefore can be seen as an example of unsuccessful implementation (Vedung 1998; Rothstein 1994; Johansson and Fogerlgren, 2016). In addition, this example is a complex one including both cooperation and conflict, and it also suffered from the absence of social worker involvement.

\section{Cooperation and conflict}

New institutional theory ultimately rests on the notion that institutions are social constructions; that is, something that people create and continuously recreate through interaction (Johansson 2002; Meyer and Rowan 1977). In this case, interactions and individual actors play important roles. Interaction in the organisational field occurs both vertically and horizontally, and can involve both cooperation and competition 
(Johansson 2013). This, too, is clearly evident between the primary responsible authorities at the national level (in this case, SALAR and the Ministry of Health and Social Affairs) and the National Board of Health and Welfare, where interaction involves both cooperation and signs of competition. This is also obvious at the regional level, where informal negotiations are continually ongoing and become part of the operations. This constitutes a political aspect of the field theory concerned with protecting one's position and autonomy (Sahlin-Andersson 1989). It concerns adaptation for the purpose of winning the struggle for advantages; in this case, position and money (Bourdieu 1986).

The intervention and its actors show that knowledge development within social services in Sweden has become a complex field. There are varying grades of interaction and clear hierarchies, not least because the primary responsible authorities (SALAR and the Ministry of Health and Social Affairs) are decision-makers, and because the regional level is offered conditional funding via annual agreements. The coalition patterns, together with competitive circumstances and clear, positioning 'power-exercising characteristics' are also obvious, not least of all between the primary responsible authorities and the National Board of Health and Welfare as well as between the primary responsible authorities and the universities and colleges. The least visible groups as actors are the local social workers and the users ${ }^{\mathrm{iii}}$. It is appropriate to suspend the discussion momentarily here in order to discuss the role of professionals in the intervention.

\section{Professional social workers in a 'knowledge-based social services'}

It is evident that the most frequently occurring opinion is that this is a top-down project, and that this intervention and its implementation have not put the social workers in focus. The social workers as street-level bureaucrats (Lipsky, 1980) have not been included in the process of the intervention aimed at changing their knowledge base and their line of work (Johansson and Fogelgren, 2016).

This intervention was aimed at changing social workers' way of working. The criticism directed at social workers today centres around the belief that they should resist a more 'intuitive' approach and instead focus on an approach supported by reason: 'Therefore, methods should be designed to combat these natural tendencies among practitioners and to more or less force them to follow a rational and conscious problem-solving process' (Rosen 2006:235). That is to say, it is the social worker's knowledge, skills, and methods that should be changed, or in other words, an entire professional practice: 
Unlike evaluation, the concept of EBP always includes the ambition to influence the design of a future (professional) practice. (Bergmark \& Lundström, 2006:101)

It should be noted that the debate and research about professional social workers focuses more on what happens after the implementation than on how social workers should be involved as central actors in the ongoing process. As such, there exists an implicit (and perhaps also explicit) idea that professional social workers neither should be involved nor do they have the requisite knowledge to be able to be involved in the implementation, and should simply wait for guidelines to be provided by other actors. Ultimately, the discussion is about what power social workers should have and what position professionals should be given: a more active, decision-making role or a more passive, supervisory role.

Other critics, such as Webb (2001), have also warned about the tendency to develop a naive faith that it is possible to implement EBP without a reflexive approach focusing on the social worker and the relationship between social workers and users.

Furthermore, this kind of intervention has elements of power as well as governance.

The final part of this article aims at analysing the now-ended intervention in a context of power and governance. The article ends with a description of some trends in the further EBP and governance development of Swedish social work. These trends are connected to the concept of governance and power

\section{Governance and power}

The 'governance' of social service practices is a concept found in an increasing number of Swedish central government reports and similar documents. In line with this ongoing and growing emphasis on centralized government control of knowledge issues in the social services, in 2015 the government decided on a reform to further define and coordinate national-level responsibility.

It is now worth asking what the state and other actors, such as SALAR, researchers, and national, regional, and local bureaucrats and politicians, actually mean when they talk about 'governance'; and, in particular, how the concept will guide the further development of social services practices and social welfare in general. These are important questions, given that all change within organisations involves elements of power and governance. New institutional theory helps us to uncover what has happened in recent years, but aspects of governance and power and the further development need to be clarified with the help of another theory. 
This intervention also constitutes an example of policy implementation (Vedun 1998; Rothstein 1994). Policy-oriented research on implementation has revealed how public decision-makers have increasingly lost confidence in large-scale programmes with centralised management. Implementation now takes on 'softer' forms: cooperation, alliances, evaluation, and fund allocation among a 'polyphony' of participants (Villadsen 2008). Today, the state cannot govern societal processes by itself, and therefore increasingly enters into agreements and partnerships with suitable organisations to achieve this. In a study of one current agreement between the Swedish state and civil society, this is referred to as 'collaborative governance' (samrådsinriktad styrning). The intervention described in this article points to the presence of this new form of collaborative implementation, while at the same time there is unmistakable evidence of power and governance.

Rhodes (1996) believes that new cooperation models should mean changes in the previous hierarchical and authoritarian political forms of governance. New forms of cooperation are assumed to lead to the participation of cooperative partners on equal terms, which leads to joint governance, dialogue, and decisions based on consensus (Hedlund and Montin 2009; Pierre and Sundström, 2009). Another, more critical concept in analysing and discussing power and governance is governmentality (Johansson 2007).

The background of governmentality can be found in Foucault's (1991) view and research on power and knowledge, a relational power that is closely related to knowledge and the effects of which have changed over the course of history. This is a wielding of power that is always based on or interacts with an attitude towards that which is to be governed (Johansson 2007). It is not about forcing laws on others, but instead about using laws tactically to achieve desired aims. Governance is achieved through individuals' freedom. 'Government' (the state, the rulers) can in itself stand for 'the conduct of conduct' in the sense of leading, governing, and guiding. However, there is also a self-regulating function within the term, as it can also mean 'to behave' (Dean 1999).

A governance analysis from the perspective of governmentality aims to discern modern governance practices, to highlight the practitioners' way of exercising power, and to analyse rationalities and technologies. A governmentality approach explains and analyses that which is specific to the modern exercise of power, and is based on the idea that governance of a phenomenon is preceded by an attitude to the phenomenon. The 
attitude itself is seen as a collective activity that represents the knowledge, beliefs, and values individuals are socialised into, which are taken for granted and which arise from theories, ideas, and philosophies from the social and cultural environment (Dean, 1999).

As such, the organisational field with its actors thereby becomes interesting - as interesting, or perhaps even more interesting, than the intervention itself. Governance thus entails a technology that involves creating a good form of government ('good governance’) through partnerships, networks, and other instruments, rather than creating a concrete governance content (collaborative governance). We could say that in governmentality, governance becomes a discourse about government (Dean 1999). Research that focuses on the form of governance rather than its content becomes important in research about human service organisations. The implementation of the idea of EBP (or knowledge development) within social services’ practice is an example of both governance and governmentality.

The Swedish government report SOU 2008:18 illuminates the conditions for achieving knowledge management of social services, for knowledge creation, and for the development of EBP. Among other things, the report focuses on clearer definitions of knowledge management and EBP, arguing that knowledge management is not EBP, but rather a means by which to implement EBP:

Knowledge management within social services thus consists of all governance and management processes that contribute to establishing evidence-based practice, that is, practice that implements the best available knowledge and that creates and maintains, respectively, a suitable infrastructure for knowledge creation and development (SOU 2008:18:7).

The future of knowledge development (including EBP) within social services thereby constitutes a good example of governmentality and 'governance' through the emergence of a horizontal network with parties outside social services' practice that are focused on consensus. On the other hand, SALAR and the Ministry of Health and Social Affairs have the power and preferential right of interpretation, while other actors such as professionals, researchers, civil servants, and clients appear to have little influence over the future of knowledge development within social services. As such, in a way there exists an indistinct division of responsibility in practice, which one could say benefits those who are already powerful; in this case, the Ministry of Health and Social Affairs and SALAR. These power structures are not revealed by new institutional theory, because the actor perspective of this theory is too weak.

Governance researchers have observed a changed view of political governance that I believe can be seen within the framework of the political control of Swedish 
social policy. Concepts like 'governance' and 'governmentality' are useful in describing these changes. If one takes this governance seriously, then there is cause for concern regarding the effect of the trend on vulnerable groups such as social service clients. At present, Swedish social services at a local level seem to be more and more governed, at least for the immediate future, by the national government through SALAR, the National Board of Health and Welfare, and other such bodies, and this seems to amount to neo-liberal governance.

Knowledge management as liberal technocracy in human service organisations The future as described within social work, both politically and scientifically, centres around the idea that social work practice needs to become 'more evidence-based, for the benefit of the user' (SOU 2008:18). This intervention seems to be not only about preparing social services and social work in general for 'the future', but also about organising and directing citizens, professionals, organisations, institutions, and discourses here and now, for the purpose of achieving pre-determined political aims.

According to the neo-liberal model, governance appears as a form of pan-societal intervention that has come to be characteristic of our time. One of liberal society's characteristics is that we are increasingly 'governed' towards freedom. The liberal governance rationality is based on belief in the possibility and desirability of effectively governing the public sphere through legislation, planning, policy, and regulation. In the liberal governance rationality, a new field of knowledge is created in which 'experts' step forward. These experts constantly produce new true, neutral, and objective knowledge that can be used to govern (Rose 1995:42; Johansson 2012). This increasing freedom simply means that we are governed in a different way, not governed less.

Within human service organisations and social work in particular, a host of different actors representing various levels interact, and their efforts (in one way or another) are legitimised as authoritative, sensible, and capable of steering and guiding social work in the 'right direction'. These actors are initially representatives for the central government and SALAR, and in the next step also for the regional level. Today, both social work and other human service organisations alike find themselves at an organisational (and methodological) crossroads. I would like to suggest that this situation also constitutes ideological crossroads.

On what foundation should the social service and other human service organisations rest? And how should the work be organized? The question is: who owns, and who will own in the future, the preferential right of interpretation concerning knowledge and the knowledge discourse that will steer social work? The rationality that emerges as the 
winner from this intervention will guide the future production of rationality, and thereby acquire power and control over future social work and similar human service organisations. This article ends with some final prospective conclusions.

\section{Governance, power, and knowledge in tomorrow's social services}

This article describes and discusses how Sweden's central government has been working with the implementation of an intervention. This intervention is sometimes described as a sweeping change to social services, as a development of social services, and even as a paradigm shift in social work.

Others have the impression that, at this time, nearly ten years after the SOU 2008:18 report was presented, the state has not come much closer to achieving long-term support for strategic knowledge development in social services (Soydan 2010, Börjeson 2012; Bohlin \& Sager 2011). Why not? Globally, the long-term results of these efforts in terms of NPM as well as EBP have been questioned in several ways (e.g. Hood 1991; Newman 2008). In Sweden, the evaluation by the Swedish Agency for Public Management (2014:18) does give some partial explanations for the still 'undeveloped knowledge base' and the ongoing need for this, but these explanations are insufficient. An analysis of the national level revealed that the intervention's content was not welldefined, and was expected to be decided through negotiation; that is, the intervention's content was expected to be clarified and processed in the future. The indistinctness of the intervention opens both opportunities and a debate about EBP, which at least initially is likely to be something other than 'for the benefit of the client'. This incompletely-defined approach implies a change in the separation of powers, and questions have been raised about the negotiating parties and the transparency of the process (Denvall and Johansson 2012).

This article shows that the state's intentions have been interpreted and re-interpreted at the regional level as well as the local level, and that the intervention has not yet created any radical change in social work practice. The intervention suffers from two basic flaws. Firstly, it is a top-down, policy-driven process. Secondly, to quote Soydan:

Importantly, policy tends to drive practice in Sweden rather than vice versa, and the demand for EBP was not professionally driven in its initial stages (Soydan, 2010:181).

This intervention also seems to be something more than just preparing the social services and social work practice in general to benefit the client; it is also about organising and directing citizens, professionals, organisations, institutions, and discourses in order to achieve certain political goals. As I have shown, this is an 
ongoing movement towards evidence-based governance. I argue that evidence-based governance is a successor of NPM, though far from a complete replacement. The SOU 2008:18 report highlighted, among other things, the conditions for knowledge development and management. After NPM, the central authorities (SALAR and the National Board of Health and Welfare) hold the resources and, through translation, are also directing practice. Moreover, actors such as researchers, professionals, and clients seem to have limited influence over future knowledge development within social services.

Despite the challenges and dilemmas, I believe that this intervention may still be a step forward. However, future work needs to focus on making social work more robust in terms of organisation, and on a more intensive and long-term collaboration between practice and research in everyday tasks as well as in more organisation-related and broad questions. Further development in social services depends on several actors, as well as on how governance and governmentality develop. The new government bill says that:

There is a need for more knowledge about the approach, processes, governance, mode of operation, and organization to promote a knowledge-based and innovative healthcare and social services from a national, regional, and local perspective. (Regeringens Proposition/Government proposition 2016/17: 50 p. 99-100, author's translation)

I agree that there is a need for knowledge of the organization and implementation of new knowledge and its processes in the human service organizations. Montin (2009) discusses the focus on results, control, and standardisation in terms of governing based on distrust. The ambition to imitate private sector markets has been realised at the expense of organizational trust in professional judgement, or expertise. This motion towards governance informed by mistrust has been observed as unfavourable and new efforts are now promoted from the national government in terms of governing public administration.

Professions, staff, citizens, patients, service users, and their relatives possess significant knowledge and experience which must be taken into consideration in the development of welfare services. (Regeringens Proposition/Government proposition. 2016/17:50:99)

In order to achieve this, the proposition highlights the concept of trust as an alternative way to run the public sector. In contrast to governance by mistrust, control, and NPM, trust-based governance is connected to the paradigm of New Public Governance (Øllgaard Bentzen 2016) where the governing of public organizations is based on mutual trust between politicians, managers, and street-level professionals (cf. Lipsky 1980). The need for improved professional work and 
knowledge development is not controversial, and neither is the need to establish better connections between research and practice in social welfare (Marsh and Fisher 2007; Johansson 2017). However, achieving this goal will require both that social services are recognized as a human service organization and that street-level bureaucrats’ desire for knowledge is taken into account. Finally, governance as a replacement for NPM must be critically researched and used, and also be critically understood as a governmentality. It remains to be seen whether trust-based governance will solve this.

\section{References}

Alexanderson, K, Beijer, E, Bengtsson, S, Hyvönen, U, Karlsson, P-Å, Nyman, M, 2009, Producing and consuming knowledge in social work practice: research and development activities in a Swedish context, Evidence \& Policy, 5, 2, 127-39

Berger, PL, Luckmann T, 1966, Kunskapssociologi. Hur individen uppfattar och formar sin sociala verklighet, Falun: Wahlström \& Widstrand. Translation by Synnöve Olsson

Bergmark, A, Bergmark, $\AA$, Lundström, T, 2012, The mismatch between the map and the terrain - evidence-based social work in Sweden, European Journal of Social Work, 15, 4, 598-609

Bergmark, A, Lundström, T, 2006, Mot en evidensbaserad praktik? Om färdriktningen i socialt arbete, Socialvetenskaplig Tidskrift, 13, 2, 99-113

Bohlin, I, Sager, M, 2011, (eds.) Evidensens många ansikten. Evidensbaserad praktik i praktiken. Lund: Arkiv

Braun, V, Clarke, V, 2014, What can “thematic analysis” offer health and wellbeing researchers? International Journal of Qualitative Studies on Health and Well-being, Vol. 9, Oct 16, 2014. ArtID: 26152

Börjeson, M, 2012, opinion piece:

http://www.dagenssamhalle.se/debatt/utvecklingsarbetet-inom-socialtjaensten-gravteftersatt-1943

Bouckaert, G, Pollitt, C, 2011, Public management reform - a comparative analysis: new public management, governance, and the neo-Weberian state (3rd edition), New York: Oxford University Press

Bourdieu, P, 1986, The forms of capital, in J. Richardson (ed) Handbook of theory and research for the sociology of education, New York: Greenwood, 241-258

Czarniawska, B, Bernward J, 1998, Winds of organizational change: how ideas translate into objects and actions, in N. Brunsson, J-P, Olsen (eds) Organizing organizations, Bergen-Sandviken: Fagbokforlaget

Czarniawska, B, Bernward, J, 1996, Travels of ideas, in B. Czarniawska, G. Sevón (eds) Translating organizational change, Berlin: Walter de Gruyter

Daly, M, 2003, Governance and social policy, Journal of Social Policy, 32, 1, 113-128

Dean, M, 1999, Governmentality: power and rule in modern society, London: Sage Publications

Denvall, V, Johansson, K, 2012, Kejsarens nya kläder - implementering av evidensbaserad praktik i socialt arbete [The Emperor's New Clothes - implementation of evidence-based practice in social work], Socialvetenskaplig tidskrift 19, 1, 26-45 
Foucault, M, 1991, Governmentality, in G. Burchell, G. Colin, P. Miller (eds) The

Foucault effect: studies in governmentality, Chicago: The University of Chicago Press, 87-104

Hasenfeld, Yeheskel (2010) "The attributes of Human service organizations". I: Hasenfeld, Yeheskel (red.) Human services as complex organization, 2 uppl. Los Angeles: Sage.

Hedlund, G, Montin, S, 2009, Governance på svenska, Stockholm: Santérus, Academic Press

Hood, C, 1991, “A public management for all seasons?”, Public Administration, vol. 69, s. 3-19.

Johansson K, 2012, Mellan stöd och kontroll, Prevention riktad mot föräldrar, barn och unga, in Petersson, K, Dahlstedt, M, Plymoth, B (eds) Fostran av framtidens medborgare: Normer och praktiker bortom välfärdsstaten, Lund: Sekel

Johansson, K, 2007, Välfärdsstat som styrning, in Lövgren, S, Johansson, K (eds) Viljan att styra: Individ, samhälle och välfärdens styrningspraktiker, Lund: Studentlitteratur

Johansson, K, 2013, Kunskapsutveckling, makt och styrning, in S. Linde, K. Svensson (eds) Förändringens entreprenörer och tröghetens agenter. [Change contractors and inertia agents], Stockholm: Liber

Johansson, K, Denvall, V, Vedung, E, 2015a, After the NPM wave. Evidence-based practice and the vanishing client. Scandinavian Journal of Public Administration, 19, 2, 69-88

Johansson, K, Fogelgren, M, 2016, En urvattnad glimt av något som kunde blivit bra. -Om professionella i socialtjänsten och den evidensbaserade praktiken. [A watered-down glimpse of something that could have become good. -About professionals in social services and evidence-based practice.] Linköping: Linköpings Universitet, CKS-rapportserie 2016:8

Johansson, K 2017, Socialtjänsten utvecklas med stöd i forskningen. I Att äga framtiden. Perspektiv på kommunal utveckling. Syssner J, Häggroth S, Ramberg U (eds), Centrum för kommunstrategiska studier (CKS) LiU Linköping University Electronic Press.

Johansson, R, 2002, Nyinstitutionalismen inom organisationsanalysen, Lund: Studentlitteratur

Johansson, S, Dellgran, P, Höjer, S (eds) 2015b, Människobehandlande organisationer: villkor för ledning, styrning och professionellt välfärdsarbete, Stockholm: Natur \& Kultur

Lipsky, M, 1980, Street-level bureaucracy. Dilemmas of the individual in public services. New York: Russell Sage Foundation

Marsh, Peter \& Mike Fisher. 2007. The development of problem-solving knowledge for social care practice, British Journal of Social Work, (38): 971-987.

Meyer, JW, Rowan, B, 1977, Institutional organizations: formal structure as myth and ceremony, American Journal of Sociology, 83, 340-63

Montin, S, Hedlund, G, 2009, Governance som interaktiv samhällsstyrning - gammalt eller nytt i forskning och politik? in Hedlund, G, Montin, S (eds) Governance på svenska, Stockholm: Santérus, Academic Press

Newman, J, Glendinning, C and Hughes, M, 2008, "Beyond modernisation? Social care and the transformation of welfare governance”, Journal of Social Policy, vol. 37, nr. 4, s. 531-557

Petterson, L, Wigzell, K, 1999, Socialtjänstens klienter har rätt till professionell hjälp, Dagens nyheter 6/10

Pierre, J, Sundström, G (eds), 2009, Samhällsstyrning i förändring, Malmö: Liber

Plattform för arbetet med att utveckla en evidensbaserad praktik $i$ socialtjänsten. Bilaga till protokoll vid regeringssammanträde 201006-17 nr III:8. Dnr S2009/4028/ST

Regeringens Proposition 2016/17:50 s99-100

Rhodes, RAW, 1996, The new governance: governing without government, Political Studies, 44, 652-67

Rose, N, 1995, Politisk styrning, auktoritet och expertis i den avancerade liberalismen, in K. Hultqvist, K. Peterson (eds) Foucault: namnet på en modern vetenskap och filosofisk problematik, Stockholm: HLS 
Rosen, A, 2006, Evidensbaserad praktik i socialt arbete - utmaningar och möjligheter, in B. Blom, S. Morén, L. Nygren (eds) Kunskap i socialt arbete. Om villkor, processer och användning, Stockholm: Natur och Kultur

Rothstein, B, 1994, Vad bör staten göra? Om välfärdsstatens moraliska och politiska logik, Stockholm: SNS Förlag

Røvik, KA, 2000, Moderna organisationer - trender inom organisationstänkandet vid millenniumskiftet, Malmö: Liber

Sackett, DL, Straus, SE, Richardson, WS, Rosenberg, W, Haynes, RB, 2000, Evidence-based medicine (2nd edition), London: Churchill Livingstone

Sahlin-Andersson, K, 1989, Oklarhetens strategi: organisering av projektsamarbete, Lund: Studentlitteratur

SKL, 2010, Att bygga strukturer för kunskapsutveckling inom socialtjänsten och delar av hälso- och sjukvård. Sammanfattning av 21 avsiktsförklaringar, Stockholm: SKL

SOU 2008:18, Evidensbaserad praktik inom socialtjänsten - till nytta för brukaren. Betänkande av utredningen för kunskapsbaserad socialtjänst [Evidence-based practice within social services - to the benefit of the user], Stockholm: Fritzes

Soydan, H, 2010, Evidence and policy: the case of social care services in Sweden, Evidence \& Policy, 6, 2, 179-93

Statskontoret, 2014, Evidensbaserad praktik inom socialtjänsten - slutrapport 2014:18 [Evidencebased practice in social services - final report], Stockholm: Statskontoret

Vaismoradi M, Turunen H, Bondas T.2013, Content analysis and thematic analysis: Implications for conducting a qualitative descriptive study. Nursing \& Health Sciences.15(3): 398-405.

Vedung, E, 1998, Utvärdering i politik och förvaltning, Lund: Studentlitteratur

Villadsen, K, 2008, Polyphonic welfare: Luhmann's system theory applied to modern social work, International Journal of Social Welfare, 17, 65-73

Webb, S, 2001, Some considerations on the validity of evidence-based practice in social work, British Journal of Social Work, 31 pp. 57-79

Øllgaard Bentzen, T, 2016, Tillidsbaseret styring of ledelse I offentlige organizationer - I

springet fra ambition till praxis. Ph.d.-afhandling, Roskilde Universitet, Roskilde

Överenskommelse, Ök, 2009-2016, Arliga överenskommelser. [Agreement. (2009-2015). Annual agreements] Retrieved from

http://www.skl.se/vi_arbetar_med/socialomsorgochstod/evidensbaserad-praktik-inomsocialtjansten/bakgrund-till-satsningen

\footnotetext{
i I use the term 'social service' when I refer to the Swedish 'socialtjänsten', a service conducted by the municipalities in Sweden.

ii $n$ n

iii or client.
} 